\title{
Regulation of cell proliferation and apoptosis by growth hormone during zebrafish auditory hair cell regeneration
}

\author{
Gopinath Rajadinakaran ${ }^{1}$, Huifang Sun ${ }^{1}$, Claire Rinehart ${ }^{1}$, Eric Rouchka², Michael Smith ${ }^{1 *}$ \\ From 11th Annual UT-ORNL-KBRIN Bioinformatics Summit 2012 \\ Louisville, KY, USA. 30 March - 1 April 2012
}

\section{Background}

In order to develop treatments or preventive measures for auditory hair cell loss, an understanding of both the process of auditory hair cell regeneration and factors that influence this process, is needed. Our previous microarray analysis showed that growth hormone $(\mathrm{GH})$ was significantly upregulated during zebrafish auditory hair cell regeneration, coupled with cell proliferation $[1,2]$. We further tested the effects of GH on zebrafish auditory hair cell regeneration by injecting GH after sound exposure and found that GH can efficiently promote post-trauma auditory hair cell regeneration, which may be achieved through stimulating proliferation and suppressing apoptosis [3]. In the current study, we used Next Generation Sequencing (NGS) to examine the possible GH pathways involved in zebrafish auditory hair cell regeneration.

\section{Materials and methods}

Groups of 20 zebrafish were exposed to a $150 \mathrm{~Hz}$ tone at $179 \mathrm{~dB}$ re $1 \mu \mathrm{Pa}$ RMS for $40 \mathrm{~h}$. Following acoustic exposure, the fish were injected with either phosphate buffer, $\mathrm{GH}$, or a GH antagonist. In addition, one baseline group received no acoustic stimulus or injection. RNA was extracted from the inner ear tissues and cDNA was synthesized for NGS. Data was generated using the Illumina Pipeline version SCS 2.8.0 and sequence alignment was done using TopHat. The aligned reads were then annotated using Cufflink and the differential expression of transcripts was performed by Cuffdiff. Only the statistically significant reads were used in further analysis and pathways were examined using Ingenuity Pathway Analysis (IPA).

\section{Results and conclusions}

Genes associated with cellular growth and proliferation, cell cycle, cell death, cancer, tissue development, and neurological disease were highly regulated in our data sets comparing baseline to buffer-injected fish, bufferinjected to antagonist-injected fish, and buffer-injected to GH-injected fish. Heat maps (Figure 1) and canonical signaling pathways were generated using IPA. We further examined the effect of $\mathrm{GH}$ by analyzing the $\mathrm{GH}$ receptor pathway. Interestingly, we found the JAK-STAT pathway to be highly upregulated in buffer-injected and GHinjected conditions but a strong downregulation was observed in the antagonist-injected condition. We also found the upregulation of IGF2 and downregulation of SOCS in the GH condition while the reverse was observed in the antagonist condition. These results suggest that GH influences zebrafish hair cell regeneration by promoting proliferation and suppressing apoptosis through the JAK-STAT pathway.

\footnotetext{
* Correspondence: michael.smith1@wku.edu

'Department of Biology and Bioinformatics and Information Science Center, Western Kentucky University, Bowling Green, KY 42101, USA

Full list of author information is available at the end of the article
} 

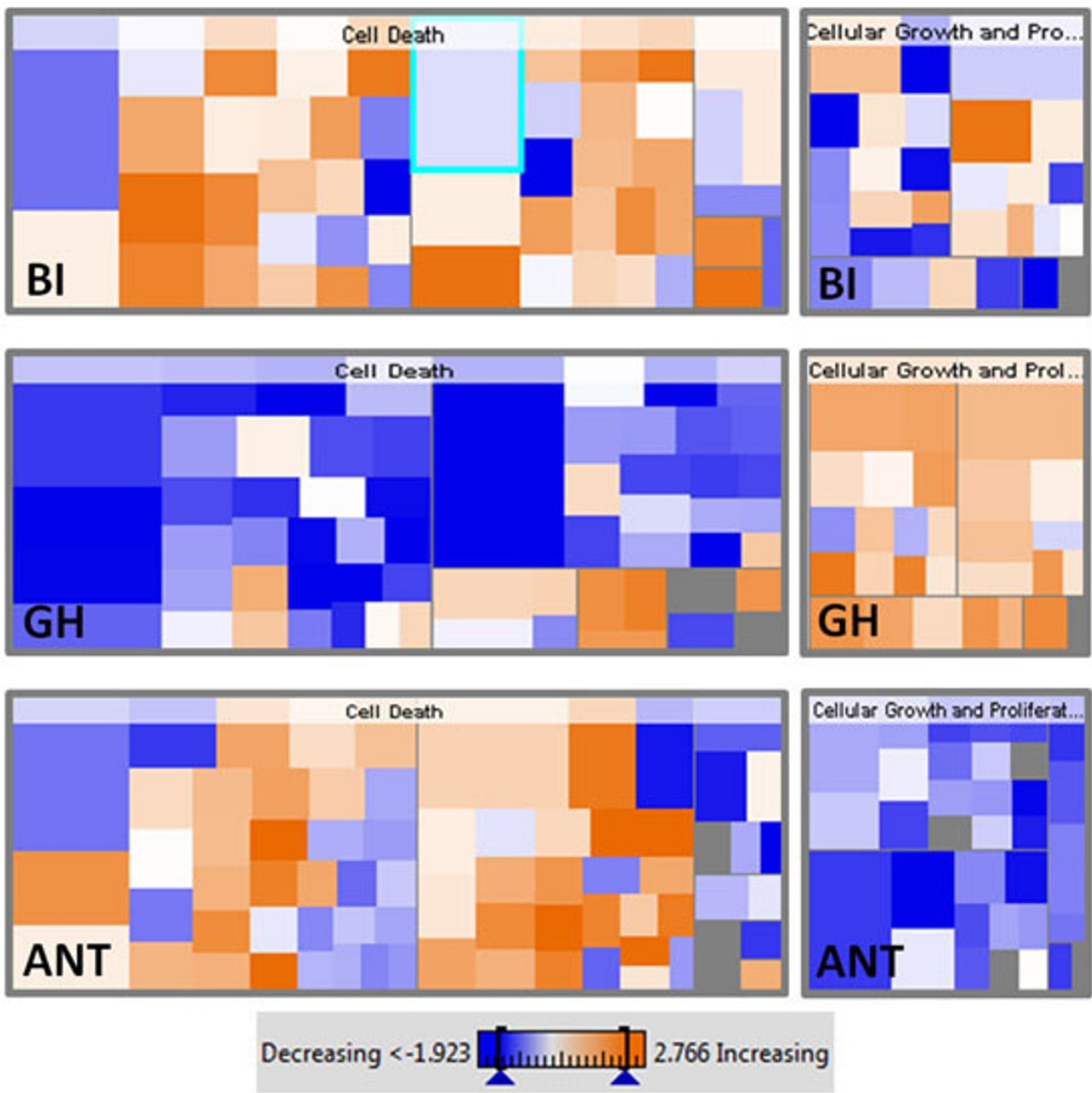

Figure 1 Heat maps for cell death and cell growth/proliferation functions generated by IPA under different treatment conditions (BIbuffer injected, GH-growth hormone, ANT-antagonist) at $\mathbf{1}$ day post-sound exposure. GH downregulates (blue) cell death pathways and upregulates (orange) cellular growth and proliferation pathways, while the opposite pattern is found for the GH antagonist.

\section{Acknowledgements}

We thank Cofactor Genomics for performing the NGS. We also thank Abdallah Eteleeb and Dr. Robert Flight of the Univ. of Louisville for their assistance with NGS analysis, and Yajie Wang and Elizabeth Malloy for RNA sample preparation. This project was supported by grants from the National Center for Research Resources (5 P20 RR016481-12) and the National Institute of General Medical Sciences (8 P20 GM103436-12) from the National Institutes of Health.

\section{Author details}

'Department of Biology and Bioinformatics and Information Science Center, Western Kentucky University, Bowling Green, KY 42101, USA. ${ }^{2}$ Department of
Computer Engineering and Computer Science, University of Louisville, Louisville, KY 40292, USA.

Published: 31 July 2012

\section{References}

1. Schuck JB, Sun H, Penberthy WT, Cooper NGF, Li X, Smith ME: Transcriptomic analysis of the zebrafish inner ear points to growth hormone mediated regeneration following acoustic trauma. BMC Neuroscience 2011, 12:88.

2. Schuck JB, Smith ME: Cell proliferation follows acoustically-induced hair cell bundle loss in the zebrafish saccule. Hear Res 2009, 253:67-76. 
3. Sun H, Lin C-H, Smith ME: Growth hormone promotes hair cell regeneration in the zebrafish (Danio rerio) inner ear following acoustic trauma. PLOS ONE 2011, 6:e28372.

doi:10.1186/1471-2105-13-S12-A3

Cite this article as: Rajadinakaran et al:: Regulation of cell proliferation and apoptosis by growth hormone during zebrafish auditory hair cell regeneration. BMC Bioinformatics 2012 13(Suppl 12):A3.

Submit your next manuscript to BioMed Central and take full advantage of:

- Convenient online submission

- Thorough peer review

- No space constraints or color figure charges

- Immediate publication on acceptance

- Inclusion in PubMed, CAS, Scopus and Google Scholar

- Research which is freely available for redistribution

Submit your manuscript at www.biomedcentral.com/submit
() Biomed Central 